\title{
Virulence determinants of MRSA causing skin and soft tissue infections among HIV patients from Chennai
}

\author{
Padma Krishnan 1*, A Nagarajan 1,2, J Suriakumar ${ }^{3,4}$ \\ From 2nd International Science Symposium on HIV and Infectious Diseases (HIV SCIENCE 2014) \\ Chennai, India. 30 January - 1 February 2014
}

\section{Background}

MRSA is a well armed pathogen with an array of virulence factors, which causes skin and soft tissue infections (SSTIs) among healthy individuals in community. Although there are few reports on MRSA causing SSTIs among HIV patients, there are no studies on their virulence determinants. Hence, the current study was done to detect the virulence determinants of MRSA causing SSTIs among HIV patients.

\section{Methods}

A total of 70 clinical isolates of Staphylococcus aureus collected from HIV patients with SSTIs were screened for MRSA using cefoxitin disc $(30 \mu \mathrm{g})$. Detection of $p v l$, $f e m A, m e c A$ of the isolates was done by triplex PCR. The enterotoxins $\mathrm{A}-\mathrm{E}, \mathrm{J}, \mathrm{K}, \mathrm{P}$ and egc cluster, exfoliatins $\mathrm{A}, \mathrm{B}$ and $\mathrm{D}$, hemolysins $\alpha, \beta, \gamma, \delta \& \gamma \mathrm{v}$, leucocidins lukDE \& lukM and innate immune evasions were detected by using multiplex PCRs using suitable $S$. aureus controls.

\section{Results}

Of the 70, 16 (22.85\%) of the S. aureus isolates causing SSTIs among HIV patients were found to be MRSA. $p v l$ was detected in 15/16 (93.75\%) of MRSA isolates. 14/22 (58.33\%) virulence determinants tested were detected among the MRSA isolates. Among enterotoxins, sea and $e g c$ gene cluster were found in all MRSA isolates tested. $11 / 16(68.75 \%)$ and 10/16 (62.50\%) MRSA isolates were found to be positive for chp and $l u k D-E$, respectively.

\footnotetext{
* Correspondence: padma.abpkn@gmail.com

'Department of Microbiology, Dr. ALM PGIBMS, University of Madras,

Chennai, India

Full list of author information is available at the end of the article
}

\section{Conclusion}

Although the MRSA percentage among HIV patients was low, prevalence of $p v l$ and other virulence determinants was found to be high among MRSA isolates causing SSTIs in HIV patients.

\section{Authors' details \\ 'Department of Microbiology, Dr. ALM PGIBMS, University of Madras, Chennai, India. ${ }^{2}$ Food Analysis Laboratory, TNFSDA, Madurai, India. ${ }^{3}$ Govt. Hospital of Thoracic Medicine, Tambaram, Chennai, India. ${ }^{4}$ Institute of Microbiology, Madurai Medical College, Madurai, India.}

Published: 27 May 2014

doi:10.1186/1471-2334-14-S3-E44

Cite this article as: Krishnan et al.: Virulence determinants of MRSA

causing skin and soft tissue infections among HIV patients from

Chennai. BMC Infectious Diseases 2014 14(Suppl 3):E44.

\author{
Submit your next manuscript to BioMed Central \\ and take full advantage of: \\ - Convenient online submission \\ - Thorough peer review \\ - No space constraints or color figure charges \\ - Immediate publication on acceptance \\ - Inclusion in PubMed, CAS, Scopus and Google Scholar \\ - Research which is freely available for redistribution

